\title{
How Connected are Canadians? Inequities in Canadian Households' Internet Access
}

\author{
Catherine A. Middleton \\ Christine Sorensen \\ Ryerson University
}

\begin{abstract}
What can be learned from an analysis of Canadian household Internet adoption patterns? Households headed by lower-income, less-educated, or older Canadians have Internet adoption rates well below the Canadian average. In contrast, households with heads who are highly educated, earn above average incomes, or are younger than 55 are adopting the Internet at rates well above the average. In the simplest of terms, privileged Canadians are online, while their less-privileged compatriots are not. What is most surprising about these findings is that very little notice has been given to them, although Internet adoption data have been available for many years.
\end{abstract}

Résumé : Quelles conclusions peut-on tirer de l'analyse des tendances canadiennes d'adoption d'Internet à la maison? Les résultats démontrent que les familles avec des chefs peu instruits, d'une faible revenue et d'un âge élevé, sont plus lents d'adopter Internet. Par contre, dans les ménages dont les chefs ont une bonne éducation, recoivent des revenues au-dessus de la moyenne canadienne ou ont moins de 55 ans, l'Internet est adopté à une vitesse plus rapide que la moyenne du pays. Autrement dit, les canadiens privilégiés sont en ligne, tandis que leurs compatriotes moins chanceux ne le sont pas. C'est surprenant que ces conclusions n'aient soulevé qu'une faible attention bien que les donées concernant le phénomène d'adoption d'Internet soient disponibles depuis plusieurs années.

Keywords: Internet adoption; Digital divide; Access to information; Policy

\section{Introduction}

Canadians have been using the Internet for more than 10 years ( $\mathrm{CA}^{*}$ net Institute, 2001), yet there is little academic research that explores Canadian Internet adoption data. This paper poses a simple question: What can be learned from an analysis of Canadian household Internet adoption patterns? Drawing on Statistics Canada's Household Internet Use Survey data, the paper argues that the muchpromoted view of Canada as one of the world's most "connected" countries masks

Catherine Middleton is an Associate Professor in the Faculty of Business and teaches in the Communication and Culture Program at Ryerson University, Toronto, M5B 2K3. E-mail: cmiddlet@ryerson.ca. Christine Sorensen is an MA student in the joint Ryerson-York Graduate Program in Communication and Culture and a Senior Research Consultant at Phase 5. E-mail: csorense@ryerson.ca.

Canadian Journal of Communication, Vol 30 (2005) 463-483

(C)2005 Canadian Journal of Communication Corporation 
unequal Internet adoption patterns. The data presented here illustrate that households headed by lower-income, less-educated, or older Canadians have Internet adoption rates well below the Canadian average. In contrast, households with heads who are highly educated, earn above-average incomes, or are younger than 55 are adopting the Internet at rates well above the average. The paper explores this uneven access in the context of the federal government's "Connecting Canadians" agenda and illustrates the large disconnect between initiatives to move government services online and the ability of citizens, especially elderly, poor, and less-educated ones, to participate in this online environment. The discussion section considers whether this uneven access is a problem, what the impacts of being disconnected are, whether the current "digital divides" can be bridged, and what actions should be taken in response to uneven household Internet access in Canada. The objectives of the paper are to present data that raise awareness of this situation, to provide the basis for further dialogue, and to motivate further research in this area.

\section{Setting the context: Connecting citizens to government}

Since the mid-1990s, the government of Canada has been promoting its vision of a "Connected Canada." In 1994, the government announced the creation of an information highway strategy (Canada, 1994), establishing the Information Highway Advisory Council (IHAC) with a vision of linking Canadians to cultural products, entertainment, business, and social services (Industry Canada, 1994).

In its 1996 report, IHAC recommended that measures be taken to "ensure affordable access by all Canadians to essential communications services" (Information Highway Advisory Council, 1996, p. 24). In 1999, the government of Canada announced its intent to further develop and promote access and connectedness (via the Internet), so as to "build new linkages between citizens and government" (Manley, 1999a, n.p.). ${ }^{1}$

The now-defunct "Connecting Canadians" initiative supported programs to connect schools, voluntary organizations, and communities to each other and to the Internet (Manley, 1999a; Manley, 1999b). In 2001, the National Broadband Task Force recommended that high-speed Internet connectivity be made available to all Canadians by 2004 (National Broadband Task Force, 2001), and programs were established to encourage the development of broadband infrastructure in underserved areas (Industry Canada, 2005a; 2005b). ${ }^{2}$ Although universal broadband access has not yet been achieved, current Industry Minister David Emerson explains that " $[u]$ nder the umbrella of our Connecting Canadians program, the government has taken steps to make sure Canadians from all communities and regions are able to participate in the modern economy" (Emerson, 2004, n.p.).

A competitive Internet service provider market (Canadian Association of Internet Providers, 2003), coupled with government initiatives to encourage the development of Internet access infrastructure, have ensured that the majority of Canadians do have the opportunity to access an affordable Internet connection from home. It is noted that there are many rural and remote communities where access is limited or unavailable (Canadian Research Alliance for Community 
Innovation and Networking, 2005), but for most Canadians, home Internet access, if they want it, is available on a commercial basis.

Over the past decade, as more and more citizens around the world have become Internet users, governments have developed strategies to move many government services online (Division for Public Administration and Development Management, 2004; Lee, Tan, \& Trimi, 2005). Often described as part of the development of an information society or knowledge-based economy, the development of electronic, or "e-government," services has been motivated by expectations of improved service delivery (ideally at a reduced cost), increased interaction between citizens and governments, and opportunities for enhancing democracy (Intergovernmental Advisory Board, 2003).

In the Canadian context, the development of effective e-government has been positioned as an integral part of the broader agenda for connecting Canadians (Longford, 2004). The Canadian government wants "to be known around the world as the government most connected to its citizens, with Canadians able to access all government information and services on-line at the time and place of their choosing" (Canada, 1999, n.p.). To further this objective, in 2001 the Treasury Board established the Government On-Line Advisory Panel. The advisory panel's recommendations (Government On-Line Advisory Panel, 2002; 2003) focused on the development of user-centric, service-focused, flexible mechanisms that would allow citizens access to services through the channel of their choice. The panel recommended that:

all federal government services are accessible through a single service "window" that may be opened on-line, over the phone, in person, or through the mail, and that clients have access to similar information at comparable levels of quality, regardless of the channel chosen. (Government On-Line Advisory Panel, 2003, p. 33)

There is no doubt that the Canadian government believes that connecting its citizens to the knowledge-based economy (by means of the Internet) is vital to future economic and social prosperity:

Connectedness is about our vision of the Canadian society we want in the $21 \mathrm{st}$ century - one with a strong, dynamic, competitive economy, and a strong lifelong-learning culture, but also one that uses connectedness to promote social cohesion, cultural expression and to build new linkages between citizens and government. (Manley, 1999b)

And although the government has expressed a desire to be at the leading edge in achieving connectedness, it can be argued that the approach it has taken has been carefully considered and measured. Over the past decade, the government has established many programs to enable connectivity among its citizens, and it has earned its place among the most connected countries in the world. With an estimated 63.01 Internet users per 100 inhabitants, Canada ranked ninth in the world in 2004 (International Telecommunication Union, 2005a), up one position from 2003 (International Telecommunication Union, 2004). (In comparison, New 
Zealand had the highest estimated Internet usage, with 81.95 users per 100 inhabitants in $2004 .^{3}$ )

As the majority of Canadians are now Internet users, it would appear that the Government On-Line (GOL) strategy is an appropriate one. Indeed, Industry Canada considers the Connecting Canadians program a "great success," citing repeated first-place rankings in Accenture Consulting's annual report on online government services and offering examples of VolNet, SchoolNet, the Community Access Program (CAP), and Smart Communities as proof that Canadians are connecting to business, community, and government (Binder, 2004). The GOL report (Canada, 2005) documents extensive usage of information and transactional services offered through various government departments' electronic delivery channels.

A person who does not have Internet access can interact with the federal government by telephone, by mail, or in person (Canada, 2005). There is a semblance of equity here, and it is implied that Canadians who do not access the Internet are at no disadvantage. But as the GOL report notes, there are efforts to move users away from the offline channels toward the online ones:

The GOL Initiative is currently developing a strategy to ensure on-line services are more widely used. As part of this strategy, we will ensure that Canadians are better informed of what services are available on-line and encourage them to take advantage of the speed, convenience and lower cost of doing business with government electronically. Take-up is also linked to migrating citizens from traditional service channels such as the telephone, mail or in-person service to the electronic channel. (Canada, 2005, n.p.)

Allen, Juillet, Paquet, \& Roy (2001) observe that the logical end result of making all government services available online is that "many of the transactions now requiring mail, phone or face-to-face processes will be digitized - taking place over the Internet" (p. 95).

Governments are becoming heavily invested in information technologies ( $\$ 880$ million has been allocated to the Canadian Government On-Line initiative as of January 2005; see Canada, 2005, Appendix A), and it seems highly unlikely that there will be any retreat from the push to move more and more citizen-government interactions online.

Furthermore, there is a shared belief among the developers of e-government services around the world that online-delivery platforms are superior to offline ones, offering economic and social empowerment and opportunity through improved access to information and knowledge (Division for Public Administration and Development Management, 2004). ${ }^{4}$ So while governments may continue to offer services offline, they consider them to be inferior to those that can be delivered through an online platform.

In summary then, while the Canadian government pays lip service to multiple channels of service delivery and meeting citizens' or clients' ${ }^{5}$ needs, it seems that over time these commitments to offline service provision will erode in the inter- 
ests of improved efficiencies and better service delivery online. The recommendation to:

put the client first, and to focus organizational resources on identifying and serving the specific needs of individual clients or groups of clients as efficiently and effectively as possible, while taking maximum advantage of the transformative potential of ICTs (Government On-Line Advisory Panel, 2003, p. 11)

is inherently contradictory for those "clients" who are not convinced of the "transformative potential" of information and communication technologies.

There is a strong theme of technological determinism that underlies e-government initiatives, as well as the broader movements toward knowledge-based economies. As the United Nations' e-government readiness report states, "The new imperative of development is to employ ICT applications across the board for creation of economic opportunities and human development" (Division for Public Administration and Development Management, 2004, p. ix). The report indicates a path from "Access to Information to Knowledge to Opportunity." While this technologically deterministic approach may sit uneasily with many, it is reasonable to suggest that this is the path being developed and promoted by governments around the world. As such, it is important to understand the extent to which citizens are able to take the first step toward accessing services through information and communications technologies.

\section{Internet adoption by Canadians}

The discussion above demonstrates the importance governments are placing on citizen access to the information society. One measure of such access is found in Internet adoption data. ${ }^{6}$ The purpose of this paper is to provide an overview of Canadian household Internet adoption data in order to understand the extent to which Canadians are able to participate in the knowledge economy that is deemed so essential by government.

There are three primary sources of Internet usage data in Canada: i) private consulting firms; ii) academic research; and iii) Statistics Canada. Consulting firms have been surveying Canadians about their Internet usage for more than 10 years. Their reports include the Canadian Inter@ctive Reid Report (Ipsos Canada, 2005), the Face of the Web study (Ipsos Insight, 2005), the Dual Digital Divide series (EKOS Research Associates Inc, 2004; Reddick \& Boucher, 2002; Reddick, Boucher, \& Groseilliers, 2000; 2001), the Internet Planner study (ACNielsen Canada, 2004), and an annual report on Internet service providers in Canada (NBI/Michael Sone Associates, 2005). Canadian businesses also conduct detailed research (on their own or with the assistance of private consulting firms) to understand potential demand for online services and to identify target markets of Internet users. This research is generally proprietary, such that most academic researchers' access to the data is limited to what is made public in press releases.

The Canadian Internet Project (Zamaria, Caron, \& Fletcher, 2005), the Canadian academic partner of the World Internet Project (Center for the Digital Future, 2005), conducted its first study of individual Canadian Internet users in 2004, and 
it plans to continue surveying Canadians on their Internet usage (or non-usage) patterns every second year. ${ }^{7}$ In addition to this large-scale data-collection effort, there are many other projects conducted by academics across Canada that explore aspects of Canadians' Internet usage. One recent example is Bakardjieva's (2005) book on the Internet in everyday life. Given this paper's focus on macro-level analysis of Canadian household Internet adoption data, these projects are not described here. ${ }^{8}$

For academic researchers, the most comprehensive, accessible source of Canadian Internet usage data is Statistics Canada (2005). The Household Internet Use Survey (HIUS) was conducted annually from 1997 to 2003 (Statistics Canada, 2003b). The survey was not conducted in 2004, and it will be replaced in 2005 by the Canadian Internet Use Survey (CIUS) (Treasury Board of Canada Secretariat, 2005), a survey that collects data on individual Canadians' Internet usage. ${ }^{9}$ Individual level data are also available from the 2000 General Social Survey (GSS) (Statistics Canada, 2000). Research based on these data is discussed below. Other relevant surveys include the Survey of Electronic Commerce and Technology (Statistics Canada, 2004b) and the Survey of Internet Service Providers (Statistics Canada, 2003a), but these are not within the scope of this paper.

\section{Literature on household Internet adoption in Canada}

When reviewing the literature on household Internet adoption in Canada, it is striking how little work has been done examining broad trends over an extended time period. We are aware of no published research that considers the 2003 HIUS data set, nor of any work that studies year-over-year trends in the HIUS data. Most of the work in this area was published between 1999 and 2002 and draws on the 1997 through 2000 HIUS data sets or the 2000 General Social Survey. The literature provides insights on determinants of Internet usage at the individual and household level and explores the characteristics of non-users. The findings show consistency in adoption and non-adoption patterns over the 1997-2000 period. Specifically, it is observed that four factors strongly influenced whether a household had Internet access or not: household income; age of the head of the household (with younger households more likely to use the Internet than older households); education level of the head of household; and family type (e.g., children or no children) (Dickinson \& Ellison, 1999a; 1999b, reporting on 1997 and 1998 data). Singh (2004) confirms these determinants of Internet usage persist in the 1999 and 2000 data, also noting that rural Canadians were less likely to use the Internet than those who lived in urban regions.

The General Social Survey data was used as a basis for articles on topics such as "Internet Use on the Cusp of the 21 st Century" (Crompton, 2001), allowing for the investigation of determinants of Internet usage at an individual level. While the GSS and HIUS surveys are not directly comparable, there are many similarities in the findings. For instance, Rotermann (2001) shows that the "most connected" Canadians are the youngest included in the survey, individuals aged 1517. Silver (2001a; 2001b) examines Internet usage by senior citizens, noting that 
in comparison with younger Canadians, seniors are far less likely to use the Internet, but also observing that seniors make up the fastest growing group of Internet users.

Crowley (2002) makes use of studies by consulting firms ACNielsen, Angus Reid Group, Environics, and Ipsos-Reid to supplement the findings of the HIUS and GSS surveys, and confirms the importance of age, education, income, and family type as determinants of Internet access. Crowley also notes that non-users face barriers related to the cost of Internet access, skill in using the Internet, location of access, and interest. Dryburgh (2001), using the 2000 GSS data, reports that the biggest barrier for non-users is cost, particularly among younger Canadians. Higher-income non-users cite lack of time as their biggest barrier to Internet adoption. Younger non-users are more interested in using the Internet than older non-users.

In addition to users and non-users, there are "dropouts," people who used the Internet at one point, but were not users when surveyed by the GSS or HIUS. Crompton, Stevenson, \& Ellison (2002) explore 2000 HIUS data pertaining to Internet "dropouts." Although Internet dropouts make up a relatively small proportion of the population, their behaviour demonstrates that Internet adoption can be transitory. The primary reasons that people dropped out of Internet usage were that they had no need for it or that the cost had become prohibitive. Less than 30\% of dropouts expected to start using the Internet again in the next year.

Reddick \& Boucher's (2002) report on the disparities among Canadian Internet users synthesizes their findings from two earlier studies (Reddick, Boucher, \& Groseilliers, 2000; 2001). This research is based on data collected by EKOS Research Associates in their Rethinking the Information Highway and Information Highway and Canadian Communication Household studies. Consistent with the findings of the HIUS and GSS data, they note that cost of access and limited technical literacy are barriers to Internet adoption and are determinants of the digital divide between Internet "haves" and "have-nots." Reddick and colleagues make the important observation that there are two types of non-users encapsulated in the notion of the digital divide, described as "near" and "far" users. The "near" users are people who do want to use the Internet, but do not have the economic or technical resources necessary to do so. In contrast, "far" users may have the economic and technical capacity to use the Internet, but they are not very interested in it. Although some far users are expected to become users over time, most of them state that they simply do not have a need to access the Internet.

Stevenson (2002) and Hirji (2004) look beyond the question of Internet adoption to assess Internet users' access to online health information. Stevenson examines the GSS and 1997 through 2000 HIUS data, showing that searching for health information has become more common over time, with $46 \%$ of users doing this in 2000. Hirji moves beyond descriptive reporting of HIUS data, questioning whether government enthusiasm toward the delivery of online healthcare information and services is warranted in an environment where more than $30 \%$ of Canadians do not access the Internet. She notes the persistence of economic barriers to 
access and highlights the specific problems in the delivery of health services caused by low literacy levels and limited technological skills, particularly among the elderly.

It is surprising that there has not been more work like Hirji's, exploring the impacts that age, education, income, or family type have in determining who is online and then assessing the appropriateness of online communication and service-delivery mechanisms. In the section that follows, data are presented to show some differences between user and non-user households, and to explore the stated reasons that households become Internet dropouts. These data can be used as the basis for an assessment of how well an information society fits the needs of various groups of Canadians.

\section{Household Internet use survey data}

This section uses five years of Statistics Canada Household Internet Use Survey data (Statistics Canada, 2003b) ${ }^{10}$ to demonstrate the characteristics of Canadian households that have not adopted the Internet. It is important to understand that these data report on Internet usage by households, not by individuals. Throughout this section, the terms "Internet user," "non-user," and "dropout" refer to households, not individuals (i.e., Internet user households, non-user households, and dropout households). The unit of analysis presents some limitations in terms of discussion of user demographics. As Fred Gault, the Director of the Science, Innovation and Electronic Information division at Statistics Canada notes, "while households can have an income, they cannot have an education or a sex" (Gault \& Peterson, 2003, p. 50). Survey respondents answered questions based on Internet usage patterns by any member of the household, but certain variables record data for the head of the household. As a result, it is not possible to conduct analysis on gender using these data. ${ }^{11}$ The age variable refers to the age of the head of the household, which does not indicate the age of the household member(s) actually using the Internet; the same is true of the education-level variable.

Internet adoption within Canadian households has been increasing fairly steadily over the past five years, as shown in Figure 1 (depicting the percentage of Canadian households in each category). Home use of the Internet is lower than overall usage, as some people who access the Internet at work, school, or other locations do not have a home Internet connection. Non-user households have never accessed the Internet. The graph does not include those households that have used the Internet in the past but were not using it regularly at the time of the survey (dropouts). The annual growth-rate figures show the growth in the percentage of households using the Internet regularly from home.

An analysis of Figure 1 alone would indicate that Internet adoption by Canadian households is proceeding in predictable ways. The number of households with regular Internet users, from home and from other locations, is increasing steadily, with the number of non-user households declining in step. The growth rate has slowed from its 2000 peak, but adoption continues on an upward trajectory.

Further analysis of these data, however, show the Internet adoption patterns in quite a different light. As has been noted in earlier research on Canadian Internet 
Figure 1: Internet users and non-users ${ }^{12}$

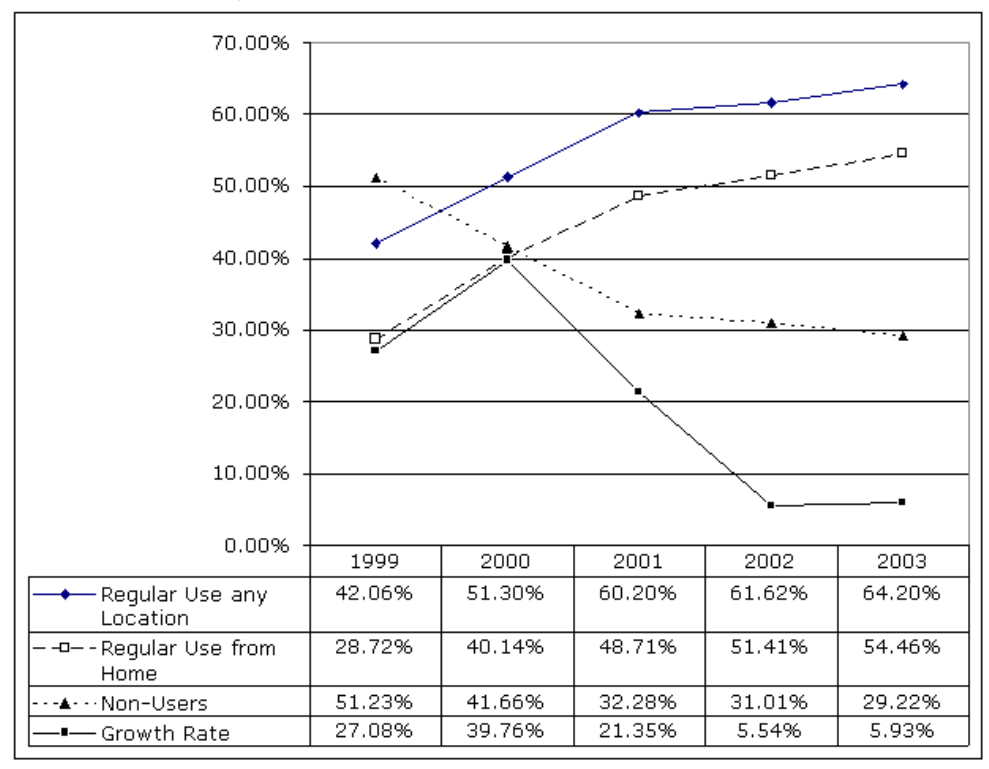

adoption, and as is consistent with other research on the digital divide (see Rice, 2002 for a review of literature in this area), adoption of the Internet varies widely on the basis of age, education, income, and family type. Focusing on non-users, Table 1 makes these differences in Canadian household adoption patterns abundantly clear. The top line, "Non-user households," shows the percentage of nonuser households reported in each year across all household types. In each section of the chart, the differences in household adoption patterns within the variables of interest are indicated. For example, although on average, fewer than $30 \%$ of Canadian households were not using the Internet in 2003, more than $70 \%$ of households headed by someone over age 65 were not Internet users. More than $60 \%$ of households headed by someone with less than high school education were not using the Internet, compared with fewer than $10 \%$ of those with university educated heads. More than $50 \%$ of households in the lowest income quartile were not Internet users, nor were more than $50 \%$ of the households composed of just one person. The "\% in population" column shows the relative size of each observed group. For example, households headed by someone over 65 years of age made up approximately $20 \%$ to $21 \%$ of the total number of households throughout the fiveyear period.

Over the five-year period of interest here, the number of non-user households with a computer in the household increased only slightly, from $23.4 \%$ in 1999 to almost $25 \%$ in $2003 .{ }^{14}$ These non-user households are of special interest, because they have the technology needed to access the Internet. Figure 2 demonstrates that their reasons for not using the Internet were complex. It does not appear that skill 
Table 1: Household Internet non-adopters by age, education, income, and family type ${ }^{13}$

\begin{tabular}{lcccccc} 
& $\begin{array}{c}\mathbf{1 9 9 9} \\
\mathbf{( \% )}\end{array}$ & $\begin{array}{c}\mathbf{2 0 0 0} \\
\mathbf{( \% )}\end{array}$ & $\begin{array}{c}\mathbf{2 0 0 1} \\
\mathbf{( \% )}\end{array}$ & $\begin{array}{c}\mathbf{2 0 0 2} \\
\mathbf{( \% )}\end{array}$ & $\begin{array}{c}\mathbf{2 0 0 3} \\
\mathbf{( \% )}\end{array}$ & $\begin{array}{c}\text { \% in } \\
\text { population }\end{array}$ \\
\hline Non-user Households & 51.23 & 41.66 & 32.28 & 31.01 & 29.22 & \\
\hline Age of Household Head & & & & & & \\
65+ years & 87.80 & 83.47 & 76.88 & 74.11 & 71.28 & $20-21$ \\
55-64 years & 62.32 & 51.38 & 40.65 & 35.95 & 33.24 & $14-15$ \\
45-54 years & 39.14 & 28.91 & 19.92 & 19.44 & 16.76 & $21-22$ \\
35-44 years & 35.07 & 24.27 & 16.38 & 15.79 & 13.36 & $22-24$ \\
25-34 years & 36.69 & 23.78 & 13.69 & 13.47 & 10.65 & $14-15$ \\
15-24 years & 33.22 & 19.34 & 8.41 & 12.03 & 10.58 & 4 \\
\hline Education of Household & Head & & & & & \\
Less than high school & 78.88 & 71.92 & 63.33 & 61.88 & 62.07 & $22-27$ \\
High school / college & 46.65 & 36.30 & 26.38 & 25.88 & 23.22 & $55-57$ \\
University degree & 21.88 & 16.37 & 10.19 & 9.61 & 8.94 & $17-19$ \\
\hline Household Income & & & & & & \\
Lowest Quartile & 74.98 & 69.56 & 59.62 & 57.92 & 57.11 & 25 \\
Second Quartile & 63.73 & 48.91 & 38.91 & 39.85 & 35.09 & 25 \\
Third Quartile & 43.80 & 31.22 & 22.28 & 18.34 & 18.36 & 25 \\
Highest Quartile & 22.51 & 16.94 & 8.32 & 7.93 & 6.33 & 25 \\
\hline Family Type & & & & & & \\
One person hhlds & 72.33 & 65.93 & 56.18 & 54.88 & 52.95 & $23-25$ \\
Family no child & 55.39 & 46.97 & 37.20 & 33.85 & 31.34 & $36-38$ \\
Multi-family & 34.79 & 25.78 & 17.16 & 16.51 & 19.11 & $4-5$ \\
Family and child & 32.22 & 20.77 & 11.93 & 11.66 & 9.33 & $32-33$ \\
\hline
\end{tabular}

level was a large concern, with only approximately $5 \%$ of non-user households with computers indicating using the Internet was "too hard" in each of the five years. Accessibility (a variable that indicates households that could not access the Internet due to being in a remote location) was also not seen as a general problem. Time constraints for non-users appear to have lessened over the years. Cost remained an important barrier to more than $20 \%$ of the non-user population. The most frequently reported reasons for not using the Internet were that users do not need or are not interested in it.

"Dropout" households are no longer using the Internet, but did use it at some point more than a year prior to the survey. In 2003, approximately $6.5 \%$ of all households were Internet dropouts. Like the non-user households, dropout households had various reasons for no longer using the Internet. As shown in Figure 3, for many households, no longer having access to a computer was a reason for dropping out. Over time, it appears that fewer people were dropping out because 
Figure 2: Non-users: Reasons for not using the Internet ${ }^{15}$

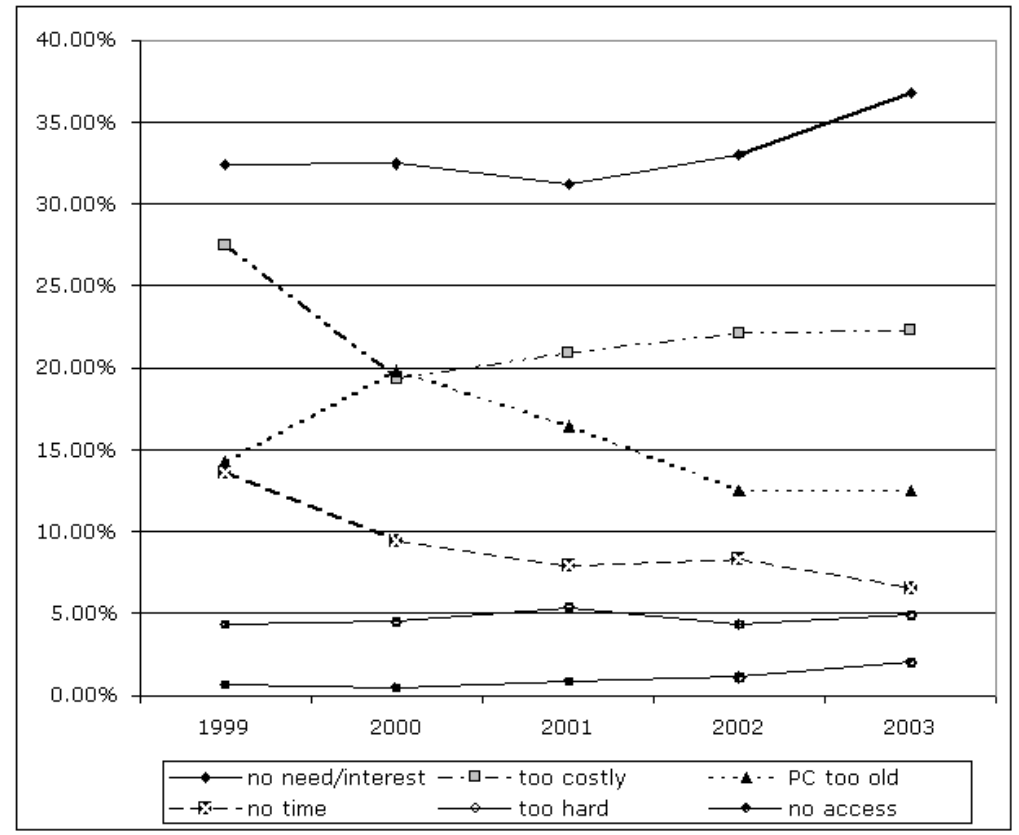

they did not need the Internet, but the cost of Internet access was a persistent concern for these households.

The data in Figure 2 and Figure 3 support the concept of a dual digital divide. Some dropouts and households that have never used the Internet indicate that the monetary cost of using the Internet is a concern, consistent with Reddick \& Boucher's (2002) "near" users. In contrast, some dropouts and non-users also indicated that they had no interest or no need for using the Internet, consistent with the "far" user group.

The apparent existence of two types of non-users among Canadian households also explains the difficulty in predicting Internet non-users. Logistic regression conducted on the HIUS data shows that family type, labour force status of the head of household, age of the head of household, education level of the head of household, and household income can be used to predict households that use the Internet from home in a typical month. As the data in Table 1 show, this is not surprising, and it is consistent with much other research on determinants of Internet access. What is interesting, however, is that the same variables are not as effective at predicting which households do not use the Internet. For example, a logistic regression conducted on the 2003 HIUS data can accurately classify $91.6 \%$ of households using the Internet, but only accurately classifies $67.3 \%$ of the nonuser households. It is suggested that "near" users can be identified based on the demographic and socioeconomic factors above. For "far" users, however, the 
determinants of Internet access are based on interest and need, rather than demographic or economic factors. The far users represent a group of households that share the basic characteristics (e.g., income, education) of Internet user households but choose not to adopt the Internet. In contrast, the near users are those who would like to adopt the Internet but are limited by economic factors. Recognizing the differences between the near and far users is critical in any effort to understand and respond to Canadian Internet adoption data.

Figure 3: Dropouts: Reasons for no longer using the Internet ${ }^{16}$

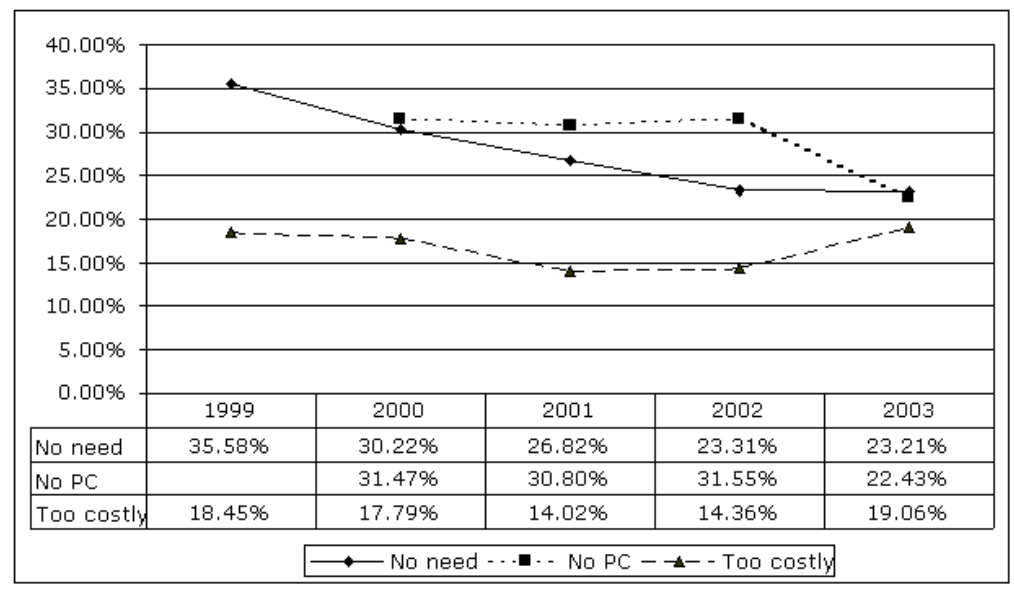

\section{Discussion}

The data presented here illustrate that households headed by lower-income, lesseducated, or older Canadians have Internet adoption rates well below the Canadian average. In contrast, households with heads who are highly educated, earn above-average incomes, or are younger than 55 are adopting the Internet at rates well above the average. In the simplest of terms, privileged Canadians are online, while their less-privileged compatriots are not. ${ }^{17}$ Although Sciadas (2002) argues that the Internet digital divide in Canada is narrowing, the more recent data show that the gaps between haves and have-nots are still pronounced. Without data for 2004 , it is difficult to know what the current situation is, but based on the trend over the previous five years, it is highly likely that the differences in household Internet adoption patterns based on age, family type, income, and education will persist, even as overall adoption rates in each category slowly increase.

This paper began by showing that the Canadian government's efforts to create and sustain a knowledge-based economy are moving us to an online environment for interacting with government. With rationales couched in terms of increased participation in the information society, improved access to government, and new opportunities for democratic participation, the assumption is that as world leaders in connectivity, Canadians are ready to embrace the Internet. While it is certainly the case that many Canadians are highly connected and completely comfortable 
searching for information and conducting transactions online, it is equally true that some Canadians have never used the Internet and are completely unprepared to adopt it for any purpose. This finding raises many questions that are worthy of further research.

\section{Question 1: Is there really a problem here?}

At first glance, it seems clear that the fact that the Canadians who are not online are those who are living alone, older, or disadvantaged by education or income represents a failure of our social systems to provide equal access to the information society. It is reasonable to conclude that despite the government fanfare promoting its success in "Connecting Canadians," it has failed to reach older and/or disadvantaged segments of society. But it is also important to question the real impacts of being disconnected by challenging the rhetoric that promotes the value of the information society.

There has been limited public discussion about whether the relentless push toward the Internet and online service delivery is appropriate, or whether it is necessary for all Canadians to participate in it. Moll and Shade's two books, published by the Canadian Centre for Policy Alternatives (Moll \& Shade, 2001; 2004), provide a strong Canadian grounding for such discussion, showing how public needs have often been overlooked by corporate interests in the development of the knowledge economy in Canada.

If the information society is not delivering on its promises, perhaps being disconnected from it is a good thing. At an individual household level, it is quite possible that being connected to government services would not provide the promised benefits of convenience and service improvement. The households that are not connected now are headed by people who are older and/or less educated than those heading households that are online. Given their expected technical and general literacy skills, the online environment could prove to be a highly intimidating place, and the offline service channels could be much more useful and accessible.

However, given the move to online interaction with citizens, we believe that it is extremely important for all Canadians to have an equal opportunity to participate in the information society. It is also important for Canadians to be able to choose not to participate, if it is not beneficial for them.

\section{Question 2: What are the impacts of being disconnected?}

Hirji (2004) provides an excellent discussion showing how individual Canadians are disenfranchised as more and more health information is moved into the online environment. It is noted that one of the priorities for Government On-Line's agenda was to transform pension, health care, and old age security services to respond to anticipated increases in demand from an aging population (Government On-Line Advisory Panel, 2003), yet this seems like precisely the wrong target for online service delivery, based on the data presented here.

Being disconnected means that citizens cannot access online resources related to health, education, and jobs, nor can they partake in the entertainment or commerce services available online. It is noted that some non-users actually use 
the Internet by proxy, having someone they know use the Internet on their behalf (Selwyn, Gorard, \& Furlong, 2005). Others rely on friends who use the Internet to provide the information they are looking for (Kayahara \& Wellman, in press). While these approaches are somewhat effective in mitigating the impacts of being a non-user, they deny non-users anonymity and freedom in their Internet activities. As Hirji (2004) notes, this is of particular concern in health care related issues.

Question 3: Can the current divides be bridged? How?

The current government agenda seems to assume that the end goal is for all Canadians to be connected. Yet on a global basis, there is no real understanding of what "full" Internet adoption might look like. Recent evidence, however, suggests that unlike devices such as telephones or even televisions, the Internet (at least in its current form) will not reach near-universal penetration rates. Data from the United States (Rainie \& Horrigan, 2005), U.K. (Selwyn, Gorard, \& Furlong, 2005), and Korea (International Telecommunication Union, 2005a; Organisation for Economic Co-operation and Development, 2005a) indicate that growth in Internet adoption in these countries appears to be stalling. For instance, in the U.S., Internet adoption rates have been estimated at $60 \%$ to $70 \%$ of the population for several years (Rainie \& Bell, 2004; UCLA Center for Communication Policy, 2003). In developed countries, Internet adoption is constrained by demand, not by supply.

The feasibility of achieving near-universal Internet adoption is not known. But if this is the desired goal, it is not clear what actions would be necessary to achieve it. One of the challenges in encouraging people to adopt the Internet is overcoming the "lack of interest" barrier among far users. Perhaps the far users will be forced online as the government retreats from multiple channels for service delivery. But without compelling reasons for going online, the far users appear quite content to remain disconnected. Is there any reason that they must become connected?

A different set of questions arises for the near users who lack the resources to go online. What are the basic standards of Internet access? Should Internet access be regulated as a universal service, like the telephone? Is it sufficient to provide Internet access at community access points (which, as Gurstein [2004] and Rideout \& Reddick [2005] note, are disappearing in Canada), or should it be a basic right for all Canadians to access the Internet from their homes? How might expectations change as access devices and platforms change? How should publicand private-sector involvement in providing access be managed? What is the role for citizen- and community-based initiatives? These questions are not new, but they have yet to be satisfactorily answered in light of current understandings of the Canadian Internet access landscape. As Clement, Moll, \& Shade (2001) note, much discussion and activist effort to improve access strategies took place before the extent of the current inequities was evident. 
Question 4: What should be done about the Canadian digital divide? By whom?

In addition to thinking about how the digital divides can be bridged, there is a more fundamental question about who should be taking action to ensure that the divides are recognized. Assuming that a convincing case has been made that there is a problem here, it is our job as researchers to gain a better understanding of the extent of the problem. Our work can provide the disconnected with the data they need to demonstrate the enormous inequities that exist at present, making a clear case that the Connecting Canadians program has in fact failed to connect many Canadian households. Champions are needed to make changes,${ }^{18}$ and they could work with existing public-interest groups to reduce the disparities in Internet access among Canadian households.

\section{Conclusions and future research}

This paper presents data describing the characteristics of Canadian households that are Internet non-users (i.e., they do not have a person in the household who regularly uses the Internet from home). It also presents data showing the reasons that non-user and dropout households do not access the Internet. The data support the notion of a dual digital divide. There are households that appear to have the educational, age, family type, or income characteristics that would allow them to adopt the Internet but have chosen not to do so, generally because of a lack of need for or interest in what the Internet offers. Other households indicate an interest in adopting the Internet but face barriers of income or literacy. The results themselves are not surprising. As has been widely reported in studies of Internet adoption around the world, age, education level, family type, and income are determinants of Internet adoption. What are somewhat surprising are the differences that exist in adoption rates within each category. It is also surprising that very little academic mention has been made of such differences.

This paper only scratches the surface of Canadian Internet adoption data. It highlights inequities in access and discusses some implications of these findings. There are many other questions to be asked about Canadian Internet adoption and usage. The HIUS data allow for analysis of intensity and scope of usage, and much can be learned from conducting detailed subgroup analysis. This paper has not discussed any regional differences in Internet adoption patterns, nor has it considered what people are actually doing when they are online. To fully understand the extent to which Canadians are prepared (or willing) to engage in the information society, a fuller understanding of their usage is required, and it can be garnered from further analysis of these data. There is also a need for analysis based on individual, rather than household, data. This will be possible with the CIUS survey and with the Canadian Internet Project data (Zamaria, Caron, \& Fletcher, 2005). There are many important issues here, and further analysis of the HIUS and analysis of the new CIUS survey can provide important insights to inform policymakers and organizations that use the Internet to engage with Canadians. 


\section{Acknowledgments}

This research was funded by SSHRC and Ryerson University. The authors wish to thank Jonathan Ellison and Claire Simard at Statistics Canada for their assistance with the Household Internet Use Survey datasets.

\section{Notes}

1. Where no page numbers are provided, the document was accessed electronically in a non-paginated format.

2. For more detail on Canadian federal policies and programs promoting Internet access, see Bodnar, Moll, \& Shade's (2005) Information and Communications Technology (ICT) Road Map: Canadian Policy Grid. Critiques of the ICT policymaking environment are provided by Birdsall (1999), Clement, Moll, \& Shade (2001), and Walters (2001), among others.

3. International statistics on Internet adoption are gathered by the ITU $(2005 \mathrm{~b})$ and the OECD (2005b). It is noted that methods of measuring Internet uptake (e.g., households vs. individuals) and data sources vary, making it difficult to compare data from different sources (e.g., national statistics agencies like Statistics Canada).

4. Such statements should not go unchallenged. It is beyond the scope of this paper to offer a critique of the knowledge-based economy and related discussions of e-governance. It is noted that the discourse is rife with assertions of benefits (Rooney, 2005), but offers scant evidence to support such assertions. Barney (2005), Chadwick \& May (2003), Fountain (2001a), Gutstein (1999), and Longford (2004) offer alternative perspectives.

5. There is a disturbing use of business terminology in documents promoting e-government. Citizens are described as customers or clients, indicating a changed understanding of the governmentcitizen relationship. Fountain (2001b) explores the perils of this approach.

6. It is important to note that adoption data simply shows whether a person has used the Internet. It provides no measure of usage behaviours, and it does not differentiate between someone who has used the Internet once or twice and someone who uses the Internet for many hours every day. The value in studying adoption data in this context is that adoption is a necessary first step for "joining" the information society. Adoption alone does not ensure that a person can take advantage of online services, for example, but non-adoption does mean that the person cannot use such services.

7. The 2004 data were released just prior to the revision of this paper in late 2005 , and although the results are relevant to this paper, there was insufficient time to incorporate them here. These data provide valuable insights on individual Internet adoption behaviours. Collected in 2004, they provide a bridge between Statistics Canada's 2003 household survey data and the forthcoming 2005 individual survey data.

8. The first author is maintaining a list of Canadian Internet research projects at URL: http:// www.broadbandresearch.ca and welcomes additions to the list.

9. Data from the 2005 survey are expected to be released in the summer of 2006.

10. The analysis presented in this paper is based on Statistics Canada microdata, which contains anonymized data collected in the 1999, 2000, 2001, 2002, and 2003 Household Internet Use Surveys. All computations on these microdata were prepared by the authors, and the responsibility for the use and interpretation of these data is entirely that of the authors.

11. As a survey of household Internet usage, the HIUS did not collect data on individuals within households. Some data is reported for the "head of the household," defined in this survey as the husband where the family type is a married couple, and as the eldest person in the household "where relationships are other than husband-wife or parent-child" (Statistics Canada, 2004a). There are two issues of concern here. As a reviewer noted, this definition of head of household is archaic. This is an important issue, but addressing it is well beyond the scope of this paper. More important for this paper is the resulting fact that throughout the seven-year history of the HIUS, no 
data are available on the gendered aspects of Internet adoption. Gault \& Peterson (2003) explain that data on computer adoption in Canada has been measured on a household basis since 1986 and note that the HIUS survey evolved from these previous measures of computer adoption. We are unaware of any published critique of the lack of individual adoption data or of the limitations that a household approach to data-collection imposes. As Gault \& McDaniel explain, "Statistics Canada surveys from which these data come respond to needs identified by the public and the policy communities" (2002, n.p.), thus arguing that it is the role of the public and of researchers to challenge the assumptions on which the data are collected.

12. HIUS data: Non-Users: GU_Q02 = No; Regular use from any location: GU_Q03 = Yes; Regular use from home: LU_Q02 = Yes. Note that "regular use from home" is a subset of "regular use from any location." The growth rates show the year-over-year change in the percentage of households with regular Internet users. Growth rates calculated on the number of households with regular Internet users are higher, as they reflect growth in the number of households, in addition to growth in Internet adoption by households.

13. HIUS data: Non-Users: GU_Q02 $=$ No; Age $=$ HAGE2; Education $=$ HEDUCL; Income $=$ Quartile; and Family Type $=$ FAMTYPE

14. PC (computer) at home: NU_Q03 = Yes.

15. Reasons non-user households with computers at home do not use the Internet: NU_Q04. (Respondents could select multiple reasons.) Responses to NU_Q04_05 (no need) and NU_Q04_13 (no interest) have been combined.

16. Dropouts are households that have used the Internet in a typical month in the past, but have not used the Internet in the twelve months prior to the survey. Reasons for no longer using the Internet: GU_Q09. (Respondents could select multiple reasons.)

17. The data do not allow conclusions to be drawn based on gender, but to the extent that gender is correlated with the variables discussed here, it would be expected that there would be gender differences in Internet adoption.

18. It is disconcerting to note that many of the public-interest groups engaged in telecommunication and information policy in the early information highway days (Clement, Moll, \& Shade, 2001) are no longer operating. A glance at the submissions to the Telecommunications Policy Review Panel (2005) shows the dominance of industry respondents and a paucity of representatives of communities and individuals.

\section{References}

ACNielsen Canada. (2004). Internet planner study. URL: http://www.acnielsen.ca/ProductsandServices/ConsumePanelServices/PanelTrackStudies/InternetPlanner.htm [24 August, 2005].

Allen, Barbara Ann, Juillet, Luc, Paquet, Gilles, \& Roy, Jeffrey (2001). E-governance \& government on-line in Canada: Partnerships, people \& prospects. Government Information Quarterly, 18(2), 93-104.

Bakardjieva, Maria. (2005). Internet society: The Internet in everyday life. Thousand Oaks, CA: Sage Publications.

Barney, Darin David. (2005). Communication technology. Vancouver, BC: UBC Press.

Binder, Michael. (2004). Keynote address: Canada in the network age: Building an infrastructure for innovation and inclusion. New York, NY: Intelligent Communities Conference and Awards.

Birdsall, William F. (1999). Policy and participation on the Canadian information highway. First Monday, 4(3). URL: http://firstmonday.org/issues/issue4_3/birdsall/index.html [1 November, 2005]. 
Bodnar, Christopher, Moll, Marita, \& Shade, Leslie Regan. (2005). Information and communications technology (ICT) road map. URL: http://www.fis.utoronto.ca/ research/iprp/cracin/policy/e-policy_map.html [15 October, 2005].

CA*net Institute. (2001). A nation goes online. Ottawa, ON: CANARIE. URL: http:// www.canarie.ca/press/publications/ ango.pdf

Canada. (2005). Government on-line 2005: From vision to reality. . . and beyond. URL: http://www.gol-ged.gc.ca/rpt2005/rpt00_e.asp [1 November, 2005].

Canada. (1994, January 18). House of Commons. Speech from the throne. URL: http://epe.lacbac.gc.ca/100/201/301/hansard-e/35-1/002_94-01-18/en002.html [13 October, 2005].

Canada. (1999, October 12). House of Commons. Speech from the throne to open the second session of the thirty-sixth parliament of Canada. URL: http://www.pcobcp.gc.ca/default.asp?Language $=$ E\&Page $=$ InformationResources $\&$ sub $=$ sftddt\&doc=sftddt1999_e.htm [20 September, 2005].

Canadian Association of Internet Providers. (2003). The Canadian ISP count, 2003: How many, where they are and what they do. Ottawa, ON. URL: http://www.cata.ca/files/ PDF/caip/industrystats/CanadianISPCount2003.pdf [25 August, 2005].

Canadian Research Alliance for Community Innovation and Networking (CRACIN). (2005). Written submission to Telecommunications Policy Review Panel. Toronto, ON: Canadian Research Alliance for Community Innovation and Networking.

Center for the Digital Future. (2005). Surveying the digital future: A longitudinal international study of the individual and social effects of PC/Internet technology. URL: http: //www.digitalcenter.org/pages/site_content.asp?intGlobalId=22 [25 August, 2005].

Chadwick, Andrew, \& May, Christopher (2003). Interaction between states and citizens in the age of the Internet: "e-government" in the United States, Britain, and the European union. Governance, 16(2), 271-300.

Clement, Andrew, Moll, Marita, \& Shade, Leslie Regan. (2001). Debating universal access in the Canadian context: The role of public interest organizations. In M. Moll \& L. R. Shade (Eds.), E-commerce vs e-commons: Communications in the public interest (pp. 23-48). Ottawa, ON: Canadian Centre for Policy Alternatives.

Crompton, Susan. (2001). Internet use on the cusp of the 21st century. Canadian Social Trends, 63, 2-3.

Crompton, Susan, Stevenson, Kathryn, \& Ellison, Jonathan. (2002). Better things to do or dealt out of the game? Internet dropouts and infrequent users. Canadian Social Trends, 65, 2-5.

Crowley, David. (2002). Where are we now? Contours of the Internet in Canada. Canadian Journal of Communication, 27(4), 469-507.

Dickinson, Paul, \& Ellison, Jonathan. (1999a). Getting connected or staying unplugged: The growing use of computer communications services. Services Indicators, 1 st Quarter, 33-50.

Dickinson, Paul, \& Ellison, Jonathan. (1999b). Plugged into the Internet. Canadian Social Trends, 55, 7-10.

Division for Public Administration and Development Management. (2004). Global e-government readiness report 2004: Towards access for opportunity. New York, NY: United Nations.

Dryburgh, Heather. (2001). Changing our ways: Why and how Canadians use the Internet. (No. 56F0006XIE). Ottawa, ON: Statistics Canada.

EKOS Research Associates Inc. (2004). The dual digital divide IV. Ottawa, ON: Ekos Research Associates Inc. 
Emerson, David. (2004). Speaking notes to the Standing Committee on Industry, Natural Resources, Science and Technology, November 25, 2004. URL: http://www.ic.gc.ca/ cmb/welcomeic.nsf/0/85256a5d006b972085256f57006d062d? Open Document [15 September, 2005].

Fountain, Jane E. (2001a). Building the virtual state: Information technology and institutional change. Washington, DC: Brookings Institution Press.

Fountain, Jane E. (2001b). Paradoxes of public sector customer service. Governance, 14(1), 55-73.

Gault, Fred, \& McDaniel, Susan A. (2002). Continuities and transformations: Challenges to capturing information about the 'information society'. First Monday, 7(2). URL: http://firstmonday.org/issues/issue7_2/gault/index.html.

Gault, Fred, \& Peterson, Greg. (2003). Measuring the diffusion of information and communication technology in society and its effects: Canadian experience. International Statistical Review, 71(1), 49-57.

Government On-Line Advisory Panel. (2002). Transforming government to serve Canadians better. Ottawa, ON: Treasury Board of Canada.

Government On-Line Advisory Panel. (2003). Connecting with Canadians: Pursuing service transformation. Ottawa, ON: Treasury Board of Canada.

Gurstein, Michael. (2004). Effective use and the community informatics sector: Some thoughts on Canada's approach to community technology/community access. In Marita Moll \& Leslie Regan Shade (Eds.), Seeking convergence in policy and practice (pp. 223-244). Ottawa, ON: Canadian Centre for Policy Alternatives.

Gutstein, Donald. (1999). E.Con: How the Internet undermines democracy. Toronto, ON: Stoddart.

Hirji, Faiza. (2004). Freedom or folly? Canadians and the consumption of online health information. Information Communication \& Society, 7(4), 445-465.

Industry Canada. (1994). The Canadian information highway: Building Canada's information and communications infrastructure. Ottawa, ON: Supply and Services Canada.

Industry Canada. (2005a). Broadband - The programs - Broadband for rural and northern development-About us. URL: http://broadband.gc.ca/pub/program/about.html [24 August, 2005].

Industry Canada. (2005b). Broadband-The programs-National satellite initiativeAbout us. URL: http://broadband.gc.ca/pub/program/nsi/aboutus.html [24 August, 2005].

Information Highway Advisory Council (IHAC). (1996). Building the information society: Moving Canada into the 21st century. Ottawa, ON: Industry Canada.

Intergovernmental Advisory Board. (2003). High payoff in electronic government: Measuring the return on e-government investments. Washington, DC: Federation of Government Information Processing Councils.

International Telecommunication Union (ITU). (2004). The portable Internet. Geneva, Switzerland: ITU.

International Telecommunication Union (ITU). (2005a). The Internet of things. Geneva, Switzerland: ITU.

International Telecommunication Union (ITU). (2005b). Statistics and analysis: International telecom statistics and analysis. URL: http:/www.itu.int/osg/spu/statistics/ [25 August, 2005].

Ipsos Canada. (2005). The Canadian inter@ctive Reid report. URL: http://www.ipsos.ca/ reid/interactive/ [25 August, 2005]. 
Ipsos Insight. (2005). The face of the web. URL: http://www.ipsos-insight.com/industryfocus/techandcomm/FOW.aspx [25 August, 2005].

Kayahara, Jennifer, \& Wellman, Barry. (In press). Searching high and low for leisure. Journal of Computer Mediated Communication, 11(4).

Lee, Sang M., Tan, Xin, \& Trimi, Silvana. (2005). Current practices of leading e-government countries. Communications of the ACM, 48(10), 99-104.

Longford, Graham. (2004). Rethinking the virtual state: A critical perspective on e-government. In Marita Moll \& Leslie Regan Shade (Eds.), Seeking convergence in policy and practice (pp. 109-140). Ottawa, ON: Canadian Centre for Policy Alternatives.

Manley, John. (1999a). Speaking notes for the Honourable John Manley Minister of Industry, Connecting Canadians day. URL: http://www.ic.gc.ca/cmb/welcomeic.nsf/0/ 85256613004a2e17852567390051ff72?OpenDocument [1 November, 2005].

Manley, John. (1999b). Canada and the Internet revolution: Connecting Canadians. [Speech]. Washington, DC: Trilateral Commission. URL: http://www.trilateral.org/ annmtgs/trialog/trlgtxts/t53/man.htm [13 October, 2005].

Moll, Marita, \& Shade, Leslie Regan. (Eds.). (2001). E-commerce vs. e-commons: Communications in the public interest. Ottawa, ON: Canadian Centre for Policy Alternatives.

Moll, Marita, \& Shade, Leslie Regan. (Eds.). (2004). Seeking convergence in policy and practice. Ottawa, ON: Canadian Centre for Policy Alternatives.

National Broadband Task Force. (2001). The new national dream: Networking the nation for broadband access. Ottawa, ON: Industry Canada.

NBI/Michael Sone Associates. (2005). Canadian Internet service providers market report, 2005 edition. Toronto, ON. URL: http://www.nbicanada.com/isp2005.html [25 August, 2005].

Organisation for Economic Co-operation and Development (OECD). (2005a, July 29). OECD broadband statistics, December 2004. URL: http://www.oecd.org/document/60/0,2340,en_2825_495656_2496764_1_1_1_1,00.html [23 August, 2005].

Organisation for Economic Co-operation and Development (OECD). (2005b). Statistics portal: Information and communication technology. URL: http://www.oecd.org/ topicstatsportal/0,2647,en_2825_495656_1_1_1_1_1,00.html [25 August, 2005].

Rainie, Lee, \& Bell, Peter. (2004). The numbers that count. New Media \& Society, 6(1), 44-54.

Rainie, Lee, \& Horrigan, John. (2005). A decade of adoption: How the Internet has woven itself into American life. Washington, DC: Pew Internet \& American Life Project.

Reddick, Andrew, \& Boucher, Christian. (2002). Tracking the dual digital divide. Ottawa, ON: EKOS Research Associates.

Reddick, Andrew, Boucher, Christian, \& Groseilliers, Manon. (2000). The dual digital divide: The information highway in Canada. Ottawa, ON: Public Interest Advocacy Centre and EKOS Research Associates.

Reddick, Andrew, Boucher, Christian, \& Groseilliers, Manon. (2001). Rethinking the information highway: Rethinking the dual digital divide. (No. RH34-17/2001E). Ottawa, ON: EKOS Research Associates Inc.

Rice, Ronald E. (2002). Primary issues in Internet use: Access, civic and community involvement, and social interaction and expression. In Leah A. Lievrouw \& Sona Livingstone (Eds.), Handbook of new media: Social shaping and consequences of ICTs (pp. 105-129). Thousand Oaks, CA: Sage.

Rideout, Vanda N., \& Reddick, Andrew J. (2005). Sustaining community access to technology: Who should pay and why. The Journal of Community Informatics, 1(2), 45-62.

Rooney, David. (2005). Knowledge, economy, technology and society: The politics of discourse. Telematics and Informatics, 22(4), 405-422. 
Rotermann, Michelle. (2001). Wired young Canadians. Canadian Social Trends, 63, 4.

Sciadas, George. (2002, November). The digital divide in Canada. Canadian Economic Observer. Catalogue no. 11-010-XPB, 3.1-3.8. Ottawa, ON: Statistics Canada.

Selwyn, Neil, Gorard, Stephen, \& Furlong, John. (2005). Whose Internet is it anyway?: Exploring adults' (non)use of the Internet in everyday life. European Journal of Communication, 20(1), 5-26.

Silver, Cynthia. (2001a). Internet use among older Canadians. Ottawa, ON: Statistics Canada.

Silver, Cynthia. (2001b). Older surfers. Canadian Social Trends, 63, 9-12.

Singh, Vik. (2004). Factors associated with household Internet use in Canada, 1998-2000. Ottawa, ON: Statistics Canada, Agriculture Division.

Statistics Canada. (2000). General social survey-Access to and use of information communication technology. (Record 4505). URL: http://www.statcan.ca/cgi-bin/imdb/ p2SV.pl?Function $=$ getSurvey\&SDDS=4505\&lang=en \&db=IMDB\&dbg $=$ f\&adm $=$ $8 \&$ dis $=2$ [23 August, 2005].

Statistics Canada. (2003a). Annual survey of Internet service providers and related services (Record 4303). URL: http://www.statcan.ca/english/sdds/4432.htm [23 August, 2005].

Statistics Canada. (2003b). Household Internet use survey. (Record 4432). URL: http:// www.statcan.ca/english/sdds/4432.htm [23 August, 2005].

Statistics Canada. (2004a). Microdata user guide household Internet use survey 2003 reference year. Ottawa ON: Statistics Canada.

Statistics Canada. (2004b). Survey of electronic commerce and technology (Record 4225). URL: http://www.statcan.ca/cgi-bin/imdb/p2SV.pl?Function=getSurvey\&SDDS= 4225\&lang $=\mathrm{en} \& \mathrm{db}=\mathrm{IMDB} \& \mathrm{dbg}=\mathrm{f} \& \mathrm{adm}=8 \& \mathrm{dis}=2$ [23 August, 2005].

Statistics Canada. (2005). Internet use in Canada: Research papers and articles. URL: http://www.statcan.ca/english/freepub/56F0003XIE/2003000/products.htm [25 August, 2005].

Stevenson, Kathryn. (2002). Health information on the net. Canadian Social Trends, 66, 7-10.

Telecommunications Policy Review Panel. (2005). Submissions Received by the Panel. URL: http://www.telecomreview.ca/epic/Internet/intprp-gecrt.nsf/en/h_rx00025e.html [1 November, 2005].

Treasury Board of Canada Secretariat. (2005). RPP 2005-2006, Statistics Canada. URL: http://www.tbs-sct.gc.ca/est-pre/20052006/SC-SC/SC-SCr5601_e.asp [23 August, 2005].

UCLA Center for Communication Policy. (2003). The UCLA Internet report: Surveying the digital future year 3. Los Angeles, CA: UC Regents.

Walters, Gregory J. (2001). Information highway policy, e-commerce and work. In Marita Moll \& Leslie Regan Shade (Eds.), E-commerce vs. e-commons: Communications in the public interest (pp. 69-94). Ottawa, ON: Canadian Centre for Policy Alternatives.

Zamaria, Charles, Caron, André H., \& Fletcher, Fred. (2005). Canada online! A comparative analysis of Internet users and non-users in Canada and the world: Behaviour, attitudes and trends 2004. Toronto, ON: Canadian Internet Project. 
